\title{
A Study of Safety Evaluation Method for Medical Diagnostic Table
}

\author{
Xiaoyan Zhang, Jia Liu, Jun Guo, Lei Feng \\ MICT Engineering Department, GE Hangwei Health Care Co. Ltd., Beijing, China \\ Email: Xiaoyan.zhang@ge.com \\ Received May 2013
}

\begin{abstract}
Medical diagnostic tables are widely used in the medical diagnostic equipment. For multifarious diagnostic needs, the medical diagnostic table works in various operating modes. In order to ensure patient safety, safety factor of medical diagnostic table must meet safety requirement. The paper puts forward a method to find relations between key parameters and stress of table, identify maximum stress modes, reduce modes number of load test, and remove conservative high stress areas from finite element analysis result, by synthesizing the stress result of finite element analysis and measurement data for various operating modes of medical diagnostic table. It will help shorten test time, avoid over strength design, and reduce table's cost. An application example of the method is presented by evaluating a specific CT medical diagnostic table. This method can be a reference for safety evaluation of all medical diagnostic tables.
\end{abstract}

Keywords: Medical Diagnostic; CT Table; Medical Equipment; Safety Factor; Stress

\section{Introduction}

Medical diagnostic tables are widely used in the medical diagnostic equipment. Usually there are CT scan table [1], MR table, X-ray table, PET table, surgery table and so on [2]. There are various supporting structure designs for medical diagnostic tables, such as scissor, actuator, parallelogram structure, and so on.

Supporting parts will bear stress. IEC60601-1 third edition [3] and relative standards require the minimum safety factor of supporting parts should be more than 2.5.

When a medical diagnostic table is designed, finite element analysis is executed firstly for the supporting parts. Using the finite element analysis result, we can find high stress areas in the parts. Because of the complexity of boundary constrain and the arithmetic limitation of the finite element analysis method, some high stress areas found are conservative. Over design will happen, if the design only relies on the result of finite element analysis. Therefore actual strain or stress measurement in high stress area is necessary.

Based on the finite element analysis result, we can figure out the high stress points on each supporting part. By measuring and investigating regular pattern of stress for those high stress points, table maximum stress modes can be identified. Such findings will be instructive and provide guidance to the actual table loading test, which is used to evaluate table's strength. It reduces modes number for the actual loading test and cost.
This paper cites an example of test of a specific CT medical diagnostic table to make detail description of the safety evaluation method. This CT medical diagnostic table under study uses parallelogram structure. It provides various operating modes, such as working on different height and different cradle extension for patient application needs.

Investigation results show that load, table height and cradle extension length impact the stress of the supporting parts. Two maximum stresses modes for all the supporting parts are found. One is maximum load, lowest patient loading table height and no cradle extension. The other is maximum load, lowest working height within the gantry bore and full cradle extension. Table's load test should be executed on both modes.

\section{CT Medical Diagnostic Table with Parallelogram Structure}

Figure 1 shows a kind of CT medical diagnostic table with parallelogram structure. It consists of cradle, up and down mechanism, in and out mechanism, covers, electrical control mechanism and so on. Cradle is used to support the patient .Up and down mechanism provides up and down movement of the table. In and out mechanism provides in and out movement of the cradle. Covers give safeguard for the patient and operator. Electrical control mechanism drives table up/down movement and cradle in/out movement. 


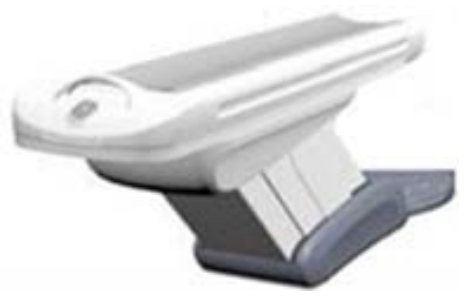

Figure 1. CT medical diagnostic table.

\section{Various Operating Modes of CT Medical Diagnostic Table}

In order to cover various operating modes of the CT medical diagnostic table, several key parameters of table are determined. They are the lowest table height for patient loading, the lowest table working height within the gantry bore for the patient scanning, the highest table working height within the gantry bore for the patient scanning, cradle not extended and cradle fully extended. Only when the table height is between the lowest and the highest working height, can cradle move in and out. For the specific CT medical diagnostic table, $525 \mathrm{~mm}$ is its lowest patient loading height, $780 \mathrm{~mm}$ is its lowest working height, $991 \mathrm{~mm}$ is its highest working height, $2045 \mathrm{~mm}$ is its maximum cradle extension length, and $306 \mathrm{~kg}$ is its maximum working load. Table 1 gives detailed description of the CT table's 18 operating modes and 1 movement process.

\section{Supporting Parts}

When patient is loaded on the cradle, the table's main supporting parts are bearing large forces, and are transferring the forces from table top to bottom. The main supporting parts on a parallelogram structure table are Cradle, Channel Support, Front Leg, Rear Leg, Base, and Frame. Figure 2 shows the main supporting parts.

\section{Strain Measurement Points}

Strain gauges are attached to the high stress areas identified from finite element analysis to get the actual stress data through measurement.

Figure 3 shows measurement points on Cradle.

Figure 4 shows measurement points on Channel Support.

Figure 5 shows measurement points on Front Leg.

Figure 6 shows measurement points on Rear Leg.

Figure 7 shows measurement points on Base

Figure 8 shows measurement points on Frame.

\section{Strain Gauges}

Right angle strain array gauges are used to measure strain of high stress points on the supporting parts. The kind of strain array is shown on Figure 9 [4]. Each piece of
Table 1. 18 typical table operating modes and 1 movement process.

\begin{tabular}{|c|c|}
\hline Work mode & Mode description \\
\hline 1 & $\begin{array}{l}\text { Table height: } 525 \mathrm{~mm} \text {. Load: } 0 \mathrm{~kg} \text {. } \\
\text { Cradle extension:0 mm }\end{array}$ \\
\hline 2 & $\begin{array}{l}\text { Table height: } 780 \mathrm{~mm} \text {. Load: } 0 \mathrm{~kg} \text {. } \\
\text { Cradle extension:0 mm }\end{array}$ \\
\hline 3 & $\begin{array}{l}\text { Table height: } 780 \text { mm. Load: } 0 \text { kg. } \\
\text { Cradle extension: } 2045 \text { mm }\end{array}$ \\
\hline 4 & $\begin{array}{l}\text { Table height: } 991 \mathrm{~mm} \text {. Load: } 0 \mathrm{~kg} \text {. } \\
\text { Cradle extension: } 0 \mathrm{~mm}\end{array}$ \\
\hline 5 & $\begin{array}{l}\text { Table height: } 991 \text { mm. Load: } 0 \text { kg. } \\
\text { Cradle extension: } 2045 \text { mm }\end{array}$ \\
\hline 6 & $\begin{array}{l}\text { Table height: } 991 \mathrm{~mm} \text {. Load: } 0 \mathrm{~kg} \text {. } \\
\text { Cradle extension: } 1022.5 \mathrm{~mm}\end{array}$ \\
\hline 7 & $\begin{array}{l}\text { Table height: } 525 \mathrm{~mm} \text {. Load: } 153 \mathrm{~kg} \text {. } \\
\text { Cradle extension: } 0 \mathrm{~mm}\end{array}$ \\
\hline 8 & $\begin{array}{l}\text { Table height: } 780 \mathrm{~mm} \text {. Load: } 153 \mathrm{~kg} \text {. } \\
\text { Cradle extension: } 0 \mathrm{~mm}\end{array}$ \\
\hline 9 & $\begin{array}{l}\text { Table height: } 780 \mathrm{~mm} \text {. Load: } 153 \mathrm{~kg} \text {. } \\
\text { Cradle extension: } 2045 \mathrm{~mm}\end{array}$ \\
\hline 10 & $\begin{array}{l}\text { Table height: } 991 \mathrm{~mm} \text {. Load: } 153 \mathrm{~kg} \text {. } \\
\text { Cradle extension: } 0 \mathrm{~mm}\end{array}$ \\
\hline 11 & $\begin{array}{l}\text { Table height: } 991 \mathrm{~mm} \text {. Load: } 153 \mathrm{~kg} \text {. } \\
\text { Cradle extension: } 2045 \mathrm{~mm}\end{array}$ \\
\hline 12 & $\begin{array}{l}\text { Table height: } 991 \mathrm{~mm} \text {. Load: } 153 \mathrm{~kg} \text {. } \\
\text { Cradle extension: } 1022.5 \mathrm{~mm}\end{array}$ \\
\hline 13 & $\begin{array}{l}\text { Table height: } 525 \text { mm. Load: } 306 \mathrm{~kg} \text {. } \\
\text { Cradle extension: } 0 \mathrm{~mm}\end{array}$ \\
\hline 14 & $\begin{array}{l}\text { Table height: 780mm. Load: 306kg. } \\
\text { Cradle extension:0mm }\end{array}$ \\
\hline 15 & $\begin{array}{l}\text { Table height: } 780 \mathrm{~mm} \text {. Load: } 306 \mathrm{~kg} \text {. } \\
\text { Cradle extension: } 2045 \mathrm{~mm}\end{array}$ \\
\hline 16 & $\begin{array}{l}\text { Table height: } 991 \mathrm{~mm} \text {. Load: } 306 \mathrm{~kg} \text {. } \\
\text { Cradle extension: } 0 \mathrm{~mm}\end{array}$ \\
\hline 17 & $\begin{array}{l}\text { Table height: } 991 \mathrm{~mm} \text {. Load: } 306 \mathrm{~kg} . \\
\text { Cradle extension: } 2045 \mathrm{~mm}\end{array}$ \\
\hline 18 & $\begin{array}{l}\text { Table height: } 991 \mathrm{~mm} \text {. Load: } 306 \mathrm{~kg} \text {. } \\
\text { Cradle extension: } 1022.5 \mathrm{~mm}\end{array}$ \\
\hline $\begin{array}{l}1 \text { Movement } \\
\text { process }\end{array}$ & $\begin{array}{l}\text { Table height: } 991 \mathrm{~mm} \text {. Load: } 306 \mathrm{~kg} \text {. } \\
\text { Cradle extension: from } 0 \text { to } 2045 \mathrm{~mm}\end{array}$ \\
\hline
\end{tabular}

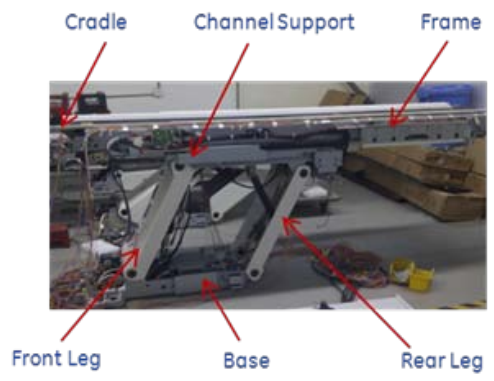

Figure 2. Main supporting parts. 


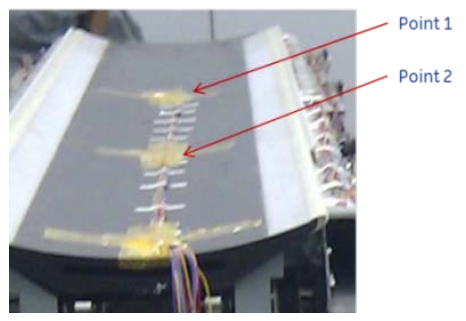

Figure 3. Measurement points on cradle.
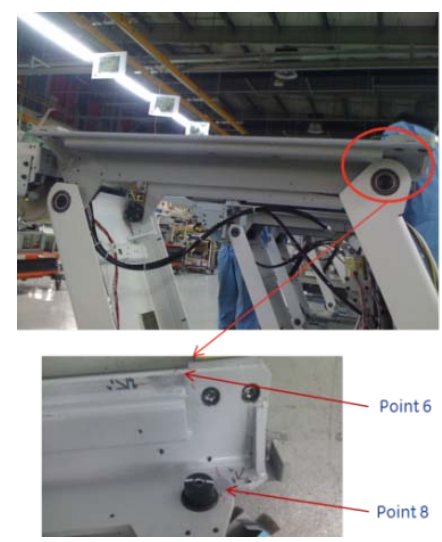

Figure 4. Measurement points on channel support.
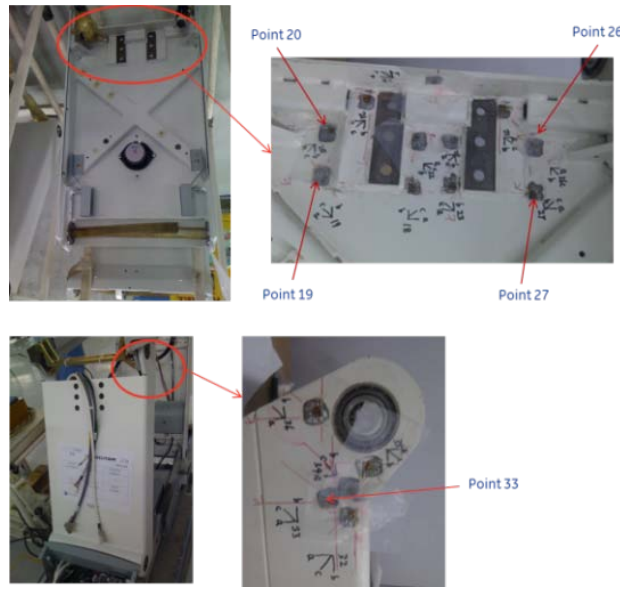

Figure 5. Measurement points on front leg.
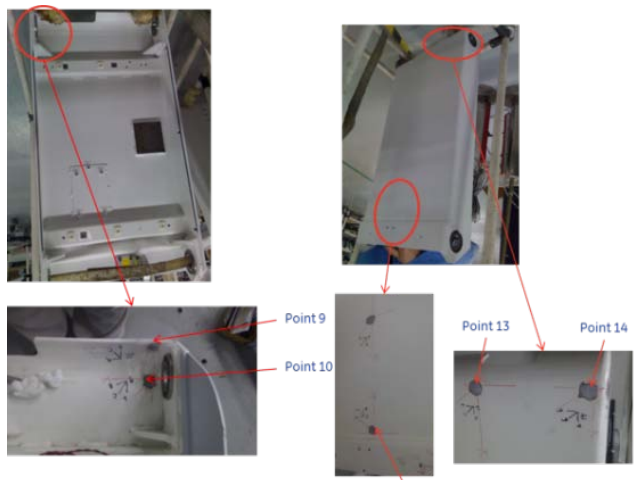

Point 11

Figure 6. Measurement points on rear leg.

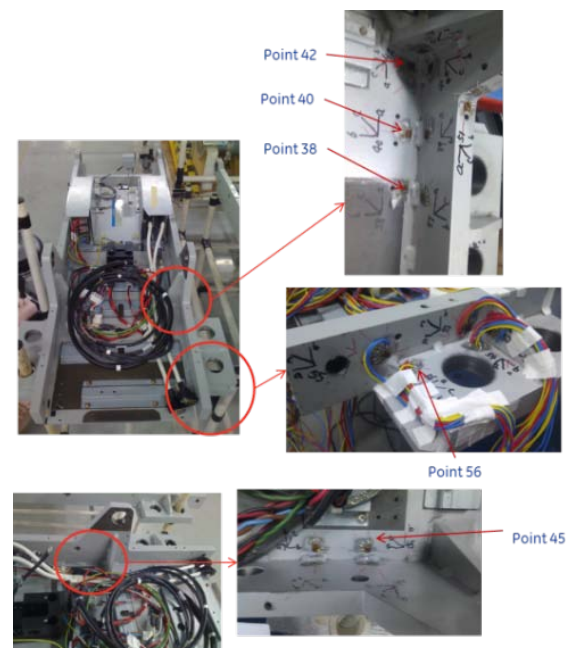

Figure 7. Measurement points on base.

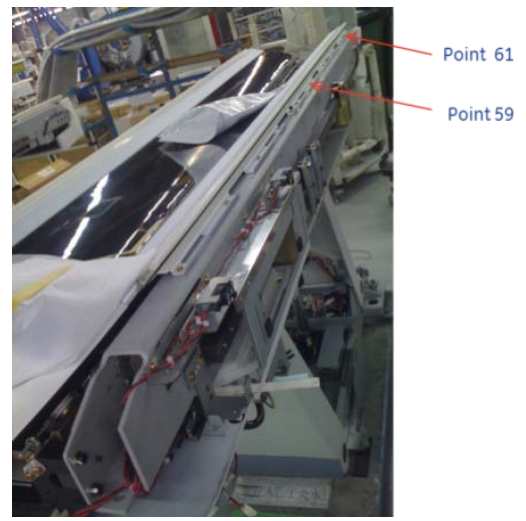

Figure 8. Measurement points on frame.
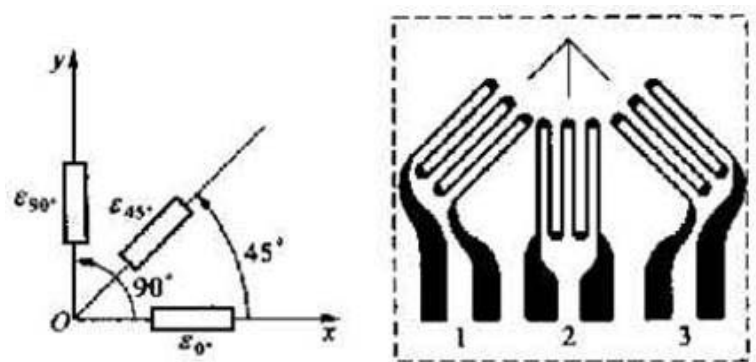

Figure 9. Right angle strain array gauge.

strain gauge array detects strain on direction $0^{\circ}, 45^{\circ}$ and $90^{\circ}$.

\section{Test Procedures}

\subsection{Attach Strain Gauge}

First, disassemble the CT medical diagnostic table. All supporting parts are in free load mode without any stress. Then remove paint around points to be measured, and where strain gauge will be attached [5]. After that, attach strain gauge with glue. Maintain 24 hours to dry the glue. 
Lastly, assemble these parts into a medical diagnostic table again.

\subsection{Acquire and Record Strain Data}

Using measurement data acquiring system, acquire and record strain data $\varepsilon_{0^{\circ}}, \varepsilon_{45^{\circ}}, \varepsilon_{90^{\circ}}$ of all strain gauges for 18 table operating modes and 1 movement process as shown in Table 1.

\section{Equivalent Stress at Measurement Point}

Based on strain data $\varepsilon_{0^{\circ}}, \varepsilon_{45^{\circ}}, \varepsilon_{90^{\circ}}$ measured by strain gauges, normal stresses $\sigma_{1}, \sigma_{2}$ [4] are:

$$
\begin{aligned}
\sigma_{1}= & \frac{\mathrm{E}\left(\varepsilon_{0^{\circ}}+\varepsilon_{90^{\circ}}\right)}{2(1-\mu)} \\
& +\frac{\sqrt{2} \mathrm{E}}{2(1+\mu)} \times \sqrt{\left(\varepsilon_{0^{\circ}}-\varepsilon_{45}\right)^{2}+\left(\varepsilon_{45^{\circ}}-\varepsilon_{90^{\circ}}\right)^{2}} \\
\sigma_{2} & =\frac{E\left(\varepsilon_{0^{\circ}}+\varepsilon_{90^{\circ}}\right)}{2(1-\mu)} \\
- & \frac{\sqrt{2} \mathrm{E}}{2(1+\mu)} \times \sqrt{\left(\varepsilon_{0^{\circ}}-\varepsilon_{45^{\circ}}\right)^{2}+\left(\varepsilon_{45^{\circ}}-\varepsilon_{90^{\circ}}\right)^{2}}
\end{aligned}
$$

where $\varepsilon_{0^{\circ}}$ is the strain on $0^{\circ}$ direction.

$\varepsilon_{45^{\circ}}$ is the strain on $45^{\circ}$ direction.

$\varepsilon_{90^{\circ}} \varepsilon^{\circ}$ is the strain on $90^{\circ}$ direction.

$\mathrm{E}$ is the elastic module of material.

$\mu$ is the Poisson's ratio of material.

Equivalent stress [6] at the point is:

$$
\sigma_{v}=\sqrt{\frac{\left(\sigma_{1}-\sigma_{2}\right)^{2}+\left(\sigma_{2}-\sigma_{3}\right)^{2}+\left(\sigma_{3}-\sigma_{1}\right)^{2}}{2}}
$$

where $\sigma_{3}$ is zero

Equivalent stress at any point can be calculated using Equations (1), (2) and (3).

\section{Investigation of Stress on Supporting Parts for 18 Table Operating Modes}

\subsection{Stress on Supporting Parts When Load Changes}

- Figure 10 shows stress on Cradle when load is $0 \mathrm{~kg}$, $153 \mathrm{~kg}, 306 \mathrm{~kg}$ for 18 table operating modes. The stress on Cradle is directly proportional to load. Maximum stress mode is mode 15 with table height $780 \mathrm{~mm}$, load $306 \mathrm{~kg}$, and Cradle extension 2045 $\mathrm{mm}$.

- Figure 11 shows stress on Channel Support when load is $0 \mathrm{~kg}, 153 \mathrm{~kg}, 306 \mathrm{~kg}$ for 18 table operating modes. The stress on Channel Support is directly proportional to load. Maximum stress mode is mode 15.

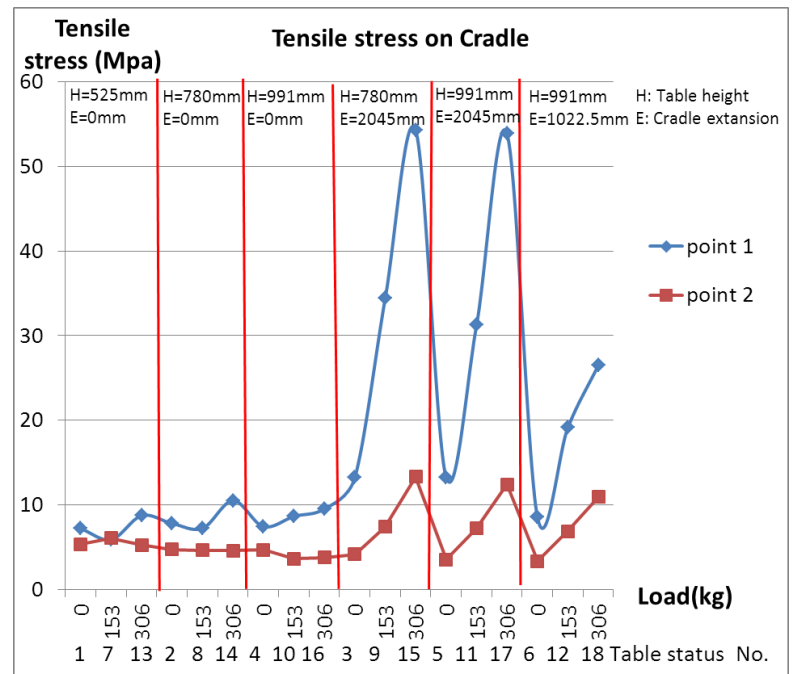

Figure 10. Stress on cradle when load changes.

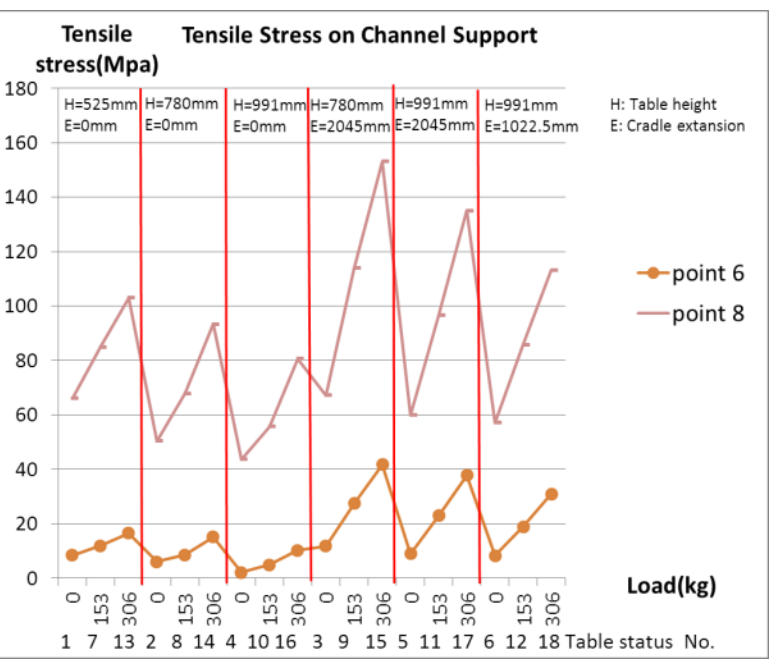

Figure 11. Stress on channel support when load changes.

- Figure 12 shows stress on Front Leg when load is 0 kg, $153 \mathrm{~kg}, 306 \mathrm{~kg}$ for 18 table operating modes. The stress on Front Leg is directly proportional to load. Maximum stress modes are mode 13 and 15 . Mode 13 is with Table height $525 \mathrm{~mm}$, load $306 \mathrm{~kg}$, and Cradle extension $0 \mathrm{~mm}$.

- Figure 13 shows stress on Rear Leg when load is 0 kg, $153 \mathrm{~kg}, 306 \mathrm{~kg}$ for 18 table operating modes. The stress on Rear Leg is directly proportional to load. Maximum stress mode is mode 15.

- Figure 14 shows stress on Base when load is $0 \mathrm{~kg}$, $153 \mathrm{~kg}, 306 \mathrm{~kg}$ for 18 table operating modes. The stress on Base is directly proportional to load. Maximum stress modes are mode 13 and 15.

- Figure 15 shows stress on Frame when load is $0 \mathrm{~kg}$, $153 \mathrm{~kg}, 306 \mathrm{~kg}$ for 18 table operating modes. The stress on Frame is directly proportional to load. Maximum stress mode is mode 15. 


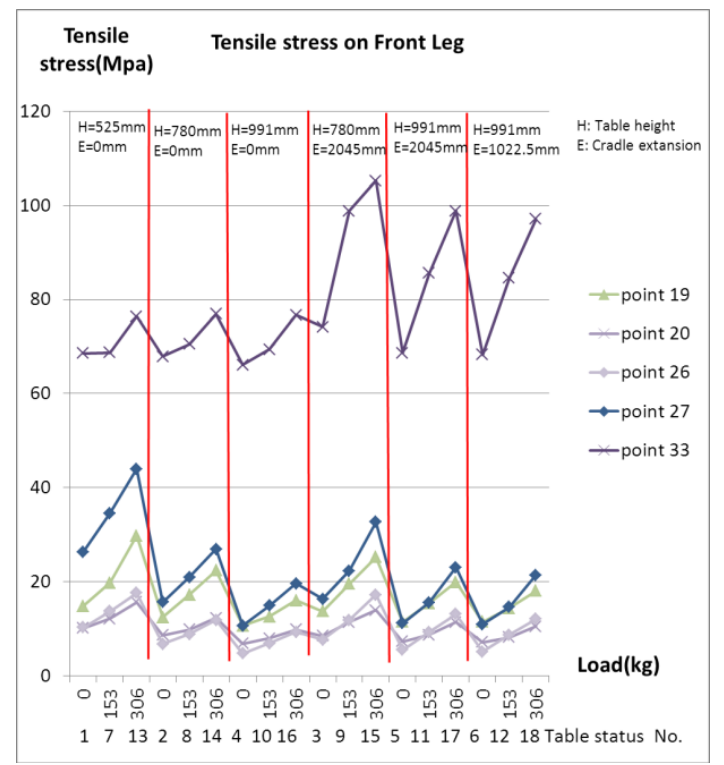

Figure 12. Stress on front leg when load changes.

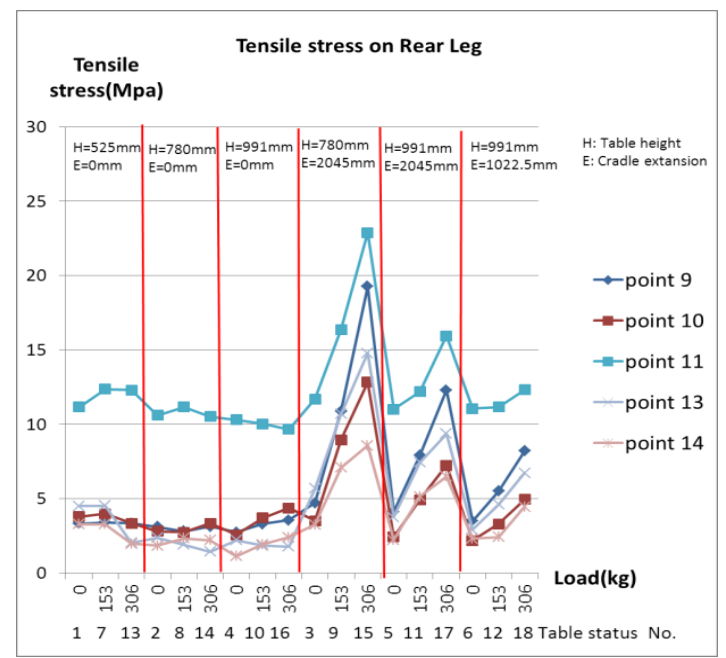

Figure 13. Stress on rear leg when load changes.

\subsection{Stress on Supporting Parts When Table Height Changes}

Stress on Channel Support, Front Leg, Rear Leg, Base and Frame are analyzed when table height changes for 18 table operating modes. The stress is inversely proportional to table height. Maximum stress modes are mode 13 , 15. Stress on cradle doesn't relate to table height.

\subsection{Stress on Supporting Parts When Cradle Extends}

Figure 16 shows stress on measurement points of Cradle when Cradle extends from $0 \mathrm{~mm}$ to full extension 2045 $\mathrm{mm}$. The stress is directly proportional to cradle extension length. But stress is not sensitive to cradle extension length when measurement points on cradle are extended

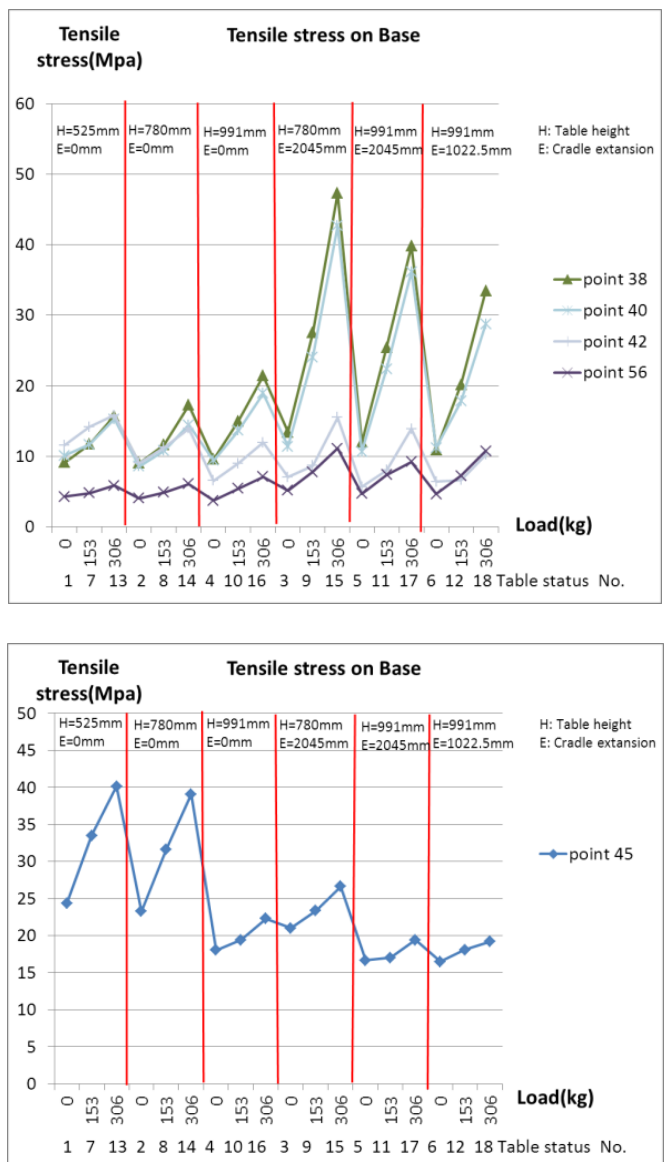

Figure 14. Stress on base when load changes.

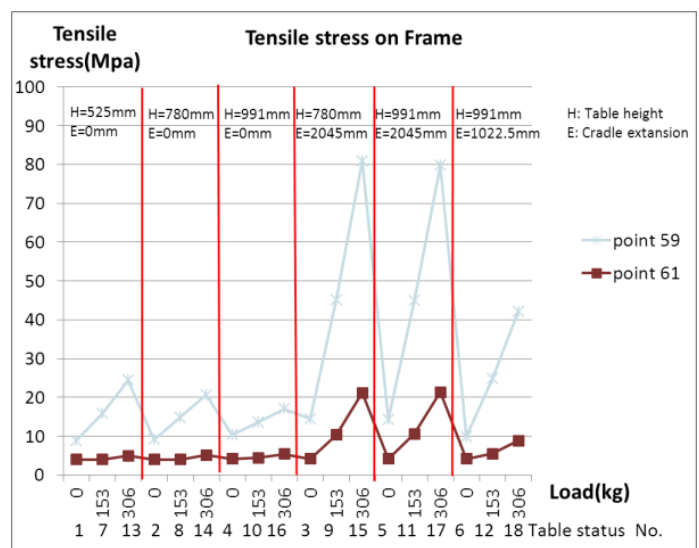

Figure 15. Stress on frame when load changes.

out of support roller.

Figure 17 shows stress on those measurement points of supporting parts, where stress is directly proportional to Cradle extension length when Cradle extends from 0 $\mathrm{mm}$ to full extension $2045 \mathrm{~mm}$.

Figure 18 shows stress on point 45 of Base, where stress is inversely proportional to Cradle extension length when Cradle extends from $0 \mathrm{~mm}$ to full extension 2045 $\mathrm{mm}$. 


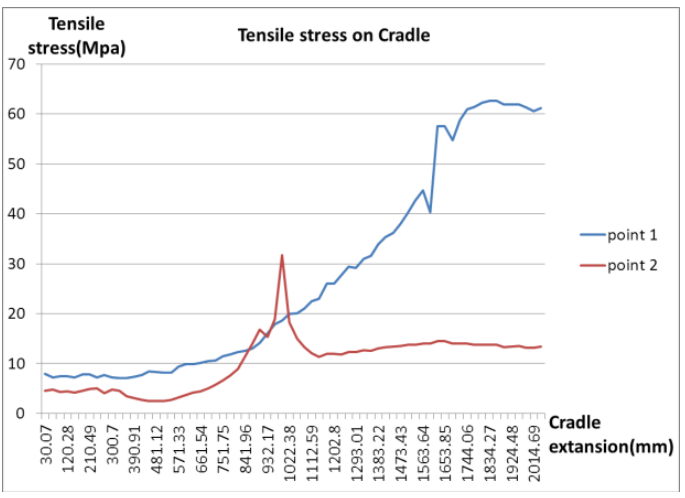

Figure 16. Stress on cradle when cradle extends.

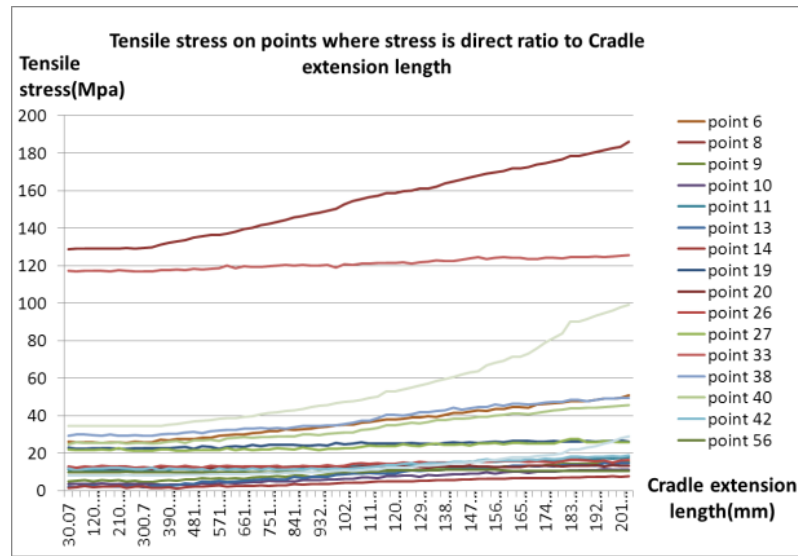

Figure 17. Stress at the points where stress is directly proportional to cradle extension length.

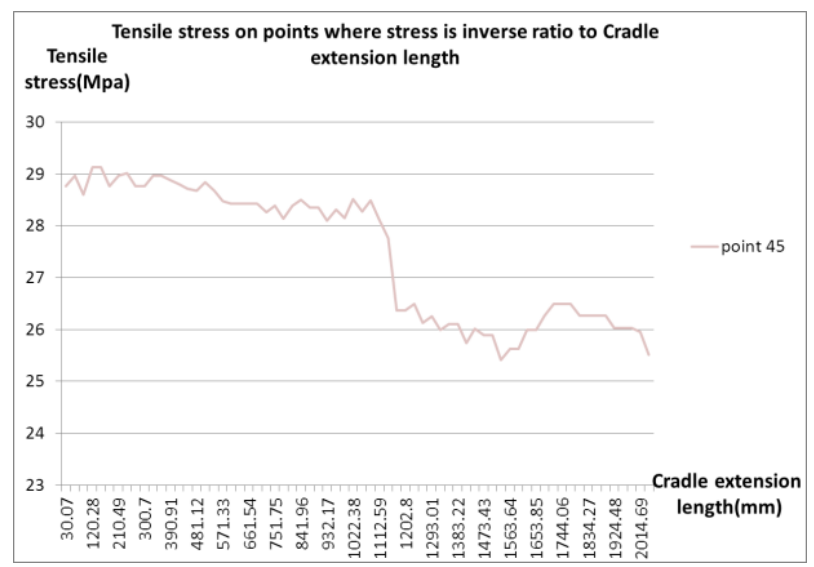

Figure 18. Stress at the point where stress is inversely proportional to cradle extension length.

\section{Maximum Stress Modes Identification}

After investigating maximum stress of each individual supporting part for 18 table operating modes, it is identified that there are 2 maximum stress modes to cover all supporting parts. One is mode 13 with lowest patient loading height $525 \mathrm{~mm}$, no cradle extension, and maximum load $306 \mathrm{~kg}$. Another is mode 15 with lowest working height $780 \mathrm{~mm}$, full cradle extension $2045 \mathrm{~mm}$, and maximum load $306 \mathrm{~kg}$.

\section{Safety Factor Evaluation}

\subsection{Strain Measurement Method to Evaluate Safety Factor of Supporting Part}

Table 2 shows safety factor of supporting parts on maximum stress modes of the CT medical diagnostic table identified by using strain measurement method. It means that safety factor of supporting parts meet IEC requirement of 2.5 .

\subsection{Load Test Method to Evaluate Safety Factor of Supporting Parts}

The method described in 11.1 is feasible to evaluate safety factor. Furthermore, based on the maximum stress modes identification result, we have developed another safety factor evaluation method. It is 4 times of maximum working load test method. When 4 times of maximum working load is put on Cradle on the maximum stress modes, if the supporting parts survive the test without any break, it means the safety factor of supporting parts is higher than 2.5 .

Figure 19 shows a load test example of the CT medical diagnostic table on the 2 maximum stress modes 13 and 15 to evaluate its safety factor. After test is completed, all supporting parts are checked, and no broken sign is found.

\section{Conclusion}

By synthesizing stress results of finite element analysis

Table 2. Safety factor of supporting parts.

\begin{tabular}{cccc}
\hline Part name & $\begin{array}{c}\text { Strength of } \\
\text { material (Mpa) }\end{array}$ & $\begin{array}{c}\text { Maximum } \\
\text { stress (Mpa) }\end{array}$ & $\begin{array}{c}\text { Safety } \\
\text { factor (Mpa) }\end{array}$ \\
\hline Channel Support & 400 & 153.1 & 2.6 \\
Front Leg & 400 & 105.2 & 3.8 \\
Rear Leg & 400 & 22.8 & 17.5 \\
Base & 400 & 47.3 & 8.4 \\
Frame & 400 & 80.8 & 4.9 \\
\hline
\end{tabular}

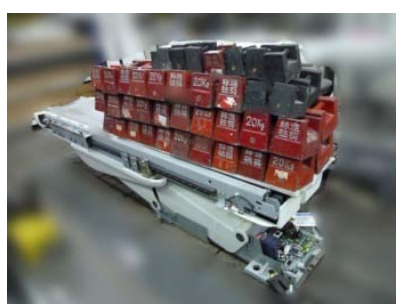

Table operating mode 13

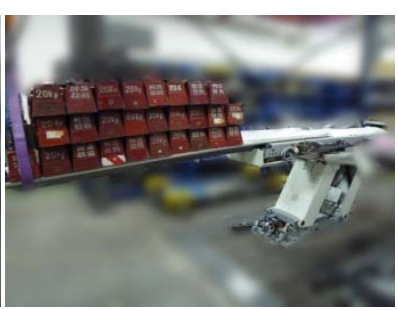

Table operating mode 15
Figure 19. Load test on CT medical diagnostic table. 
and measurement data analysis for various operating modes of a CT medical diagnostic table, the maximum stress modes are identified. Stress on supporting parts is directly proportional to load, and inversely proportional to table height. Stress on almost all points of support parts is directly proportional to cradle extension length except several points. The CT medical diagnostic table is tested using the above mentioned test method with passing result. By using this method, after the maximum stress modes of medical diagnostic table with a specific kind of supporting structure design are identified, 4 times of maximum working load test on the maximum stress modes can evaluate its safety factor. Thus modes number of load test can be reduced, some conservative high stress areas from finite element analysis result can be removed. It will help shorten test time, avoid over strength design, and reduce table cost. This method can be a reference for safety evaluation of all medical diagnostic tables.

\section{REFERENCES}

[1] J. Hsieh, “Computed Tomography Principle, Design, Artifacts and Recent Advances,” SPIE Press, Bellingham, 2009, pp. 179-205.

[2] Crotty and J. Dominic, "Patient Bed Design for an Integrated SPECT-CT Dedicated Mammotomography System,” Nuclear Science Symposium Conference Record, Vol. 6, No. 3, 2003, pp. 3915-3919.

[3] International Electrotechnical Commission, "International standard IEC60601-1,” 3d Edition, Switzerland, 2005, pp. 291-293.

[4] H. W. Liu, "Mechanics of Materials,” People’s Education Press, Beijing, 1980, pp. 200-212.

[5] J. Dia and d.-p. Wang, "Sticking Technique of Strain Gauge in Electrometric Stress-test," Journal of Hunan Institute of Engineering, Vol. 13, No. 3, 2003, pp. 55-57.

[6] H. W. Liu, "Mechanics of Materials," Higher Education Press, Beijing, 2002, pp. 322-328. 